\title{
Comprehensive assessment of aquaculture potential of the southern and south-eastern waterbodies in the Rostov region
}

\author{
Efim Kozurin ${ }^{1}$, Dmitry Rudoy ${ }^{2}$, Yuliya Kosenko ${ }^{1, *}$, Svetlana Zhukova ${ }^{1}$, Timofej \\ Barabashin $^{1}$, Arkady Babajanyan ${ }^{2}$, and David Shoniya ${ }^{2}$ \\ ${ }^{1}$ Azov-Black Sea Branch of the FSBSI « Russian Federal Research Institute of Fisheries and \\ Oceanography» (“AzNIIRKH”) Beregovaa, 344002, 21, Rostov on Don, Russia \\ ${ }^{2}$ Don State Technical University, 344003, Gagarin sq. 1, Rostov on Don, Russia
}

\begin{abstract}
The paper presents materials on a comprehensive assessment of reservoirs for commercial aquaculture, exemplified by some waterbodies in the Rostov region. We have examined 24 waterbodies located in the southern and south-eastern Rostov region. The assessment of reservoirs was carried out based on hydrological and hydrochemical indicators, the point score of which was carried out in four sets of issues. Almost all the studied water bodies because of the lack of required water supply have been classified as reservoirs with risky fish farming. Most aquaculture reservoirs recommended for commercial farming are found in the zone of a very arid climate, characterized by annual precipitation ratio of 0.33-0.44. A brief hydrochemical description of each investigated waterbody can be used to form scientifically-based recommendations for the organization of commercial fish farms in Russia.
\end{abstract}

\section{Introduction}

To manage modern fisheries, including commercial aquaculture in inland water bodies of Russia, the systematization of various information and the development of a classification or typification of water bodies based on this information is of paramount importance.

For each region, based on climatic and hydrological conditions, factors can be identified that limit the use of certain water bodies for aquaculture purposes. When developing a classification of water bodies, the main problem is the search for criteria and priority features, and, possibly, a set of a number of quantitative and qualitative indicators that should form the basis for the typification of inland water bodies. Hydrological and hydrochemical characteristics, which are the basic parameters of any ecosystem, allow one to attribute this or that water body to a certain bonitet class [1].

A comprehensive assessment of natural reservoirs for aquaculture purposes can use different criteria. Thus, for example, for the assessment of reservoirs in Sri Lanka, the productivity of reservoirs, characteristics of the catchment area and socio-economic factors were used [2]. The classification (typification) of water bodies is necessary not only for the

\footnotetext{
* Corresponding author kosenko_y_v@azniirkh.ru
} 
correct assessment of their productivity, but also should become an informational source when compiling a fishery cadastre of water bodies in the European part of the Russian Federation. All these measures will significantly expand the list of potential reservoirs where breeding of certain types of fish or aquaculture animals is promising.

According to Yu.M. Subbotina, when organizing managed fish farms, it is necessary to carry out a comprehensive fishery survey - bonitization (a comparative integral assessment of the productive forces of the reservoir ecosystem). In the course of appraisal studies, first of all, the hydrological and hydrochemical characteristics of water bodies are determined $[3]$.

The purpose of this study was to identify the hydrological and hydrochemical criteria for the typification of water bodies for the purposes of commercial aquaculture, located in the southern and southeastern regions of the Rostov region.

\section{Material and methods}

The selection of reservoirs for research in the southern and southeastern districts of the Rostov region was carried out using the list of fishing grounds for commercial fish farming and the organization of amateur and sport fishing, located within administrative boundaries of the region. The studies were carried out in the spring (May), summer (July) and autumn (October) periods of 2018. In total, 24 typical water bodies were studied.

During the research, the coordinates (location) of the waterbody were determined and the reference level of the reservoir was carried out. In order to preserve the representativeness of the data during the research, the position of sampling stations, determined by coordinates, remained unchanged in the seasonal dynamics.

Hydrometeorological studies were carried out on the basis of the Roshydromet License and included the determination of the water level, the type of water supply, the assessment of the current regime, the degree of reservoir overgrowth, transparency, color, water temperature, and the type of bottom sediments. The hydrological work was carried out in accordance with the current regulations and relevant standards.

The condition of hydraulic structures was assessed either as satisfactory or unsatisfactory, depending on the integrity and functioning. The overgrowth of waterbodies was determined visually (using a laser range finder) and was estimated as a percentage of the total area of the water body. The type of feeding of water bodies was determined according to the literature data [4-5].

The classification of reservoirs was carried out according to the State standard "Nature protection. Hydrosphere. Classification of Waterbodies ". The catchment areas were calculated using the program for constructing relief profiles: www.geocontext.org/publ/2010/04/profiler/ru and online cartographer www.mapszoom.com [6 - 9].

The following instruments and equipment were used to carry out hydrological works: GPS - navigator "GPSmap-76 Cx", laser rangefinder "Telemetrix-2 LR 140C ", a hydrometric rod GR-56, a mercury thermometer in a holder (TM-10), a probing complex" Vector-2 ", which determines the direction and speed of the current.

The working condition of all devices and equipment was confirmed by verification certificates and calibration certificates.

Water and bottom sediments were sampled from a rubber inflatable boat or in the coastal zone of waterbodies from a depth of 40-60 cm. The grain-size composition of bottom sediments was determined by the prevailing size of the constituent fractions.

The collection, processing, storage and transportation of water samples for hydrochemical analysis were carried out in accordance with the requirements of the relevant regulations [10-11]. 
The hydrochemical analysis of water samples included the determination of dissolved oxygen, water $\mathrm{pH}$, concentration of nitrate nitrogen, nitrite nitrogen, ammonium nitrogen, phosphates (for phosphorus), silicic acid, BOD5, total mineralization of water, total iron [12]. The assessment of the concentration level of indicators was carried out in accordance with the MPC for fishery waterbodies $\left(\mathrm{MPC}_{\mathrm{f}}\right)$, established by Ministry of Agriculture of the Russian Federation. Hydrochemical studies conducted in the field are presented in Figure 1.

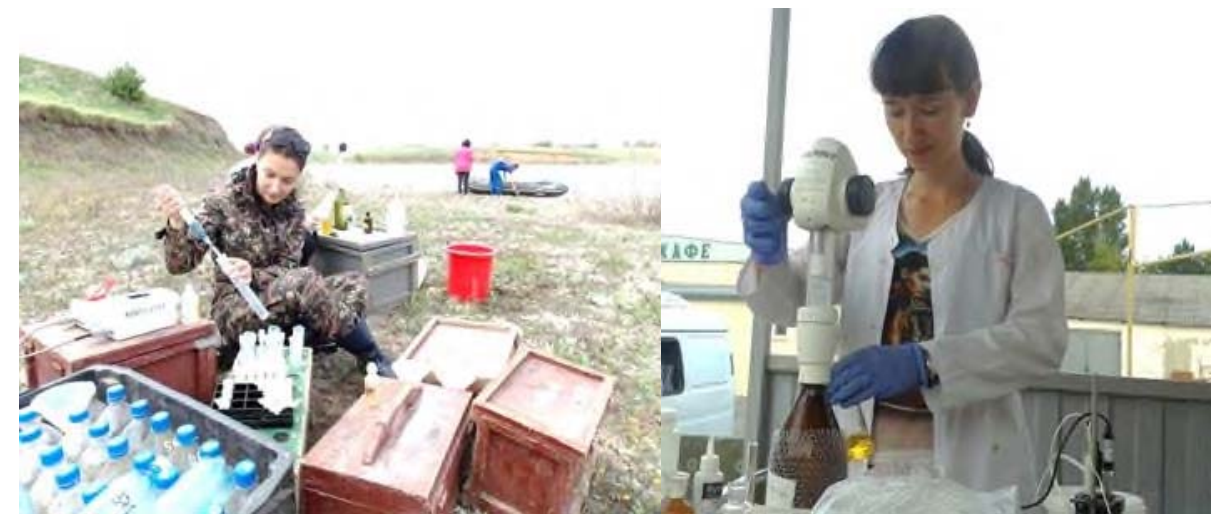

Fig. 1. Carrying out hydrochemical studies in the field

\section{Results and discussion}

Based on the results of field studies and processing of hydrochemical samples, several sets of issues had been identified, which we used to typify water bodies:

First set of issues: hydrological regime, including the study of such parameters of the reservoir as: hydrological stability (drying out - non-drying), type of feeding, type of bottom sediments, vegetation overgrowth, class, subclass of a waterbody, catchment area, as well as the nearby infrastructure and the state of hydraulic structures. According to these characteristics, the waterbodies were subdivided into three classes, indicated by the corresponding point assessment. If the body of water in terms of hydrological characteristics corresponded to the potential use for commercial aquaculture and was not very far from infrastructure, it was assigned 2 points. If a water body was recommended only after a number of reclamation measures related to dredging and clearing of springs, mowing of aquatic vegetation, removal of silt deposits (the thickness of which in many water bodies exceeds $60 \mathrm{~cm}$, and in some cases reaches $1.0 \mathrm{~m}$ or more), it was assigned 1 score. If a reservoir was not recommended for aquaculture purposes in terms of hydrological characteristics, as well as territorial location, then it was estimated at 0 points according to these criteria.

The second, third and fourth sets included the analysis of the hydrochemical regime of the investigated waterbody.

Second set of issues: the level of general water mineralization, being the most important indicator that limits the vital activity of commercial fish species (and other aquatic organisms). If the indicator of the total salinity of water in the reservoir did not exceed 6000 $\mathrm{mg} / \mathrm{dm} 3$, the estimated score corresponded to 2 points (in this case, it is possible to grow valuable commercial freshwater fish species). With a water salinity of 6000 to $12000 \mathrm{mg} /$ $\mathrm{dm} 3$, when it is possible to grow semi-anadromous fish resistant to increased salinity, the estimated score corresponded to 1.3 . If a water body has a water salinity of more than 12,000 to $36,000 \mathrm{mg} / \mathrm{dm} 3$, when it is possible to grow euryhaline anadromous and 
brackish-water fish species, the score was 0.7 points. With mineralization over $36,000 \mathrm{mg} /$ $\mathrm{dm} 3$ the estimated score corresponded to 0 .

Third set of issues: oxygen regime and factors affecting it or depending on it, i.e. oxygen directly dissolved in water, water $\mathrm{pH}$ level, hydrogen sulfide concentration in water and the level of biochemical oxygen demand.

If the oxygen regime was favorable (the oxygen concentration did not decrease below the MPC set for fishery waters $-\mathrm{MPC}_{\mathrm{f}}$ ), the $\mathrm{pH}$ level corresponded to the $\mathrm{MPC}_{\mathrm{f}}$, hydrogen sulfide was not detected and the $\mathrm{BOD}_{5}$ index did not indicate pronounced pollution of the water area with easily oxidizable organic substances (did not exceed $8.0 \mathrm{mg} / \mathrm{dm} 3$ ) 2 points were conditionally set. When a deviation of any indicator from these criteria was recorded (for example, alkalization of water or an increased level of BOD5), but critical conditions for the life of aquatic biological resources were not established, 1.3 points were set. When unfavorable conditions arose for the existence of aquatic biological resources capable of causing their rapid death, the assessment corresponded to 0.7 points. In the case when the oxygen regime was unsatisfactory, leading to the mass death of fish and aquatic organisms, this reservoir was given 0 points for block 3 .

When unfavorable conditions arose for the existence of aquatic biological resources capable of causing their rapid death, the assessment corresponded to 0.7 points. In the case when the oxygen regime was unsatisfactory, leading to the mass death of fish and aquatic organisms, this reservoir was given 0 points.

Fourth set of issues: the content of biogenic elements in water such as ammonium, nitrite, nitrate nitrogen, phosphates, silicic acid, total iron. If the concentration of nutrients in the investigated reservoir did not exceed the $\mathrm{MPC}_{\mathrm{f}}$ and did not limit the development of phytoplankton, 2 points were assigned. In the case when the concentration of biogenic substance limiting photosynthesis of phytoplankton was established or a slight excess of $\mathrm{MPC}_{\mathrm{f}}$ was revealed for one indicator, 1.3 points were set. When an excess of $\mathrm{MPC}_{\mathrm{f}}$ of several biogenic elements was found in a reservoir, 0.7 points were assigned. When the concentration of nutrients had a negative impact on the vital activity of aquatic biological resources, 0 points were given.

For a general assessment of hydrochemical characteristics, the minimum values of the points obtained in different seasons (spring, summer, autumn) of the year were used.

According to the proposed scoring characteristic, the maximum score for hydrological indicators was 2, for hydrochemical indicators it was 6 . The proposed relatively low contribution of hydrological parameters to the total score is due to the fact that it is much easier to correct the limitations associated with the hydrological regime than to influence the hydrochemical composition of water. In particular, it is theoretically and practically possible to clean the bottom from silt deposits, dredge, clear springs flowing into the reservoir, mow excess vegetation, carry out biological reclamation of the reservoir, etc. At the same time, it is practically impossible to influence the salt regime, in particular, the indicator of the total mineralization of water. The lack of nutrients in water can be corrected by the introduction of fertilizers, but at the same time their excess in the reservoir is corrected much more difficult, for example, by limiting fish feeding, lowering $\mathrm{pH}$ (when there is an excess of ammonium), increasing aeration and water exchange (with an excess of nitrites), settling or even filtering water source or sedimentation of suspension (with an excess of total iron) [13]. It is practically impossible to eliminate the excess of nitrates, phosphates and organic pollution of water in the conditions of aquaculture fish farming $[14,15]$.

The results of the scoring of each reservoir for the above sets of issues are presented in Table 1. When carrying out this assessment, based on hydrological and hydrochemical characteristics there were identified four groups of waterbodies:

Group 1: recommended for fish farming (average score from 7.0 to 8.0 points); 
Group 2: recommended for fish farming with certain restrictions (average score 5.2-6.9 points);

Group 3: recommended for fish farming with significant restrictions (average score 4.35.1 points).

Group 4: not recommended for fish farming (less than 4.2 points).

Table 1. Comprehensive assessment of the suitability of water bodies by hydrological and hydrochemical indicators for commercial aquaculture

\begin{tabular}{|c|c|c|c|c|c|c|c|c|c|}
\hline № & $\begin{array}{c}\text { Reservoir and its } \\
\text { location }\end{array}$ & $\begin{array}{l}\text { Region } \\
\text { studied }\end{array}$ & $\begin{array}{l}\text { First set } \\
\text { of issues }\end{array}$ & $\begin{array}{l}\text { Second } \\
\text { set of } \\
\text { issues }\end{array}$ & $\begin{array}{l}\text { Third } \\
\text { set of } \\
\text { issues }\end{array}$ & $\begin{array}{c}\text { Fourth } \\
\text { set of } \\
\text { issues }\end{array}$ & $\begin{array}{c}\text { Hydroch } \\
\text { emistry, } \\
\text { total }\end{array}$ & $\begin{array}{c}\text { Summa } \\
\text { rized } \\
\text { score }\end{array}$ & $\begin{array}{l}\text { Recommendation } \\
\mathrm{s} \text { for fish farming }\end{array}$ \\
\hline 1 & $\begin{array}{c}\begin{array}{c}\text { pond Chiginak, } \\
\text { hamlet }\end{array} \\
\text { Novoilovlinovskij } \\
\text { (small) }\end{array}$ & $\begin{array}{l}\text { Zavetinsk } \\
\text { ij }\end{array}$ & 1 & $\begin{array}{c}2 \\
(2 ; 2 \\
2)\end{array}$ & $\begin{array}{c}1.3 \\
(2 ; 2 \\
1.3)\end{array}$ & $\begin{array}{c}1.3 \\
(1,3 ; \\
1.3 ; 1.3)\end{array}$ & 4.6 & 5.6 & $\begin{array}{c}\text { recommended } \\
\text { with restrictions }\end{array}$ \\
\hline 2 & $\begin{array}{c}\text { the Kara-Sal river } \\
\text { hamlet Shebalin }\end{array}$ & $\begin{array}{l}\text { Zavetinsk } \\
\text { ij }\end{array}$ & 2 & $\begin{array}{c}2 \\
(2 ; 2 \\
2)\end{array}$ & $\begin{array}{c}2 \\
(2 ; 2 \\
2)\end{array}$ & $\begin{array}{c}1.3 \\
(1.3 ; 2 \\
1.3)\end{array}$ & 5.3 & 7.3 & recommended \\
\hline 3 & $\begin{array}{c}\text { gully Yablochnaya, } \\
3 \mathrm{~km} \text { of hamlet } \\
\text { Yablochnyj }\end{array}$ & $\begin{array}{c}\text { Dubovski } \\
\mathrm{j}\end{array}$ & 2 & $\begin{array}{c}2 \\
(2 ; 2 \\
2)\end{array}$ & $\begin{array}{c}1.3 \\
(1.3 \\
1.3 \\
1.3)\end{array}$ & $\begin{array}{c}1.3 \\
(1.3 ; \\
1.3 ; 1.3)\end{array}$ & 4.6 & 6.6 & $\begin{array}{c}\text { recommended } \\
\text { with restrictions }\end{array}$ \\
\hline 4 & $\begin{array}{l}\text { pond on the river } \\
\text { Yerik, } \\
\text { hamlet Yerikovskij }\end{array}$ & $\begin{array}{c}\text { Dubovski } \\
\mathrm{j}\end{array}$ & 1 & $\begin{array}{c}2 \\
(2 ; 2 \\
2)\end{array}$ & $\begin{array}{c}1.3 \\
(1.3 \\
1.3 \\
2)\end{array}$ & $\begin{array}{c}1.3 \\
(1.3 ; \\
1.3 ; 2)\end{array}$ & 4.6 & 5.6 & $\begin{array}{l}\text { recommended } \\
\text { with restrictions }\end{array}$ \\
\hline 5 & $\begin{array}{l}\text { the Big Gashun } \\
\text { river, } \\
10 \mathrm{~km} \text { north of } \\
\text { village Bajkov }\end{array}$ & $\begin{array}{l}\text { Zimovnik } \\
\text { ovskij }\end{array}$ & 0 & $\begin{array}{c}0 \\
(0.7 ; 0 \\
0)\end{array}$ & $\begin{array}{l}1.3 \\
(2 ; \\
1.3 \\
1.3) \\
\end{array}$ & $\begin{array}{c}1.3 \\
(2 ; 1.3 \\
1.3)\end{array}$ & 2.6 & 2.6 & $\begin{array}{c}\text { not } \\
\text { recommended }\end{array}$ \\
\hline 6 & $\begin{array}{c}\text { reservoir } \\
\text { Tikholimanskoje } \\
\text { Gully Keresta }\end{array}$ & $\begin{array}{l}\text { Remontn } \\
\text { enskij }\end{array}$ & 2 & $\begin{array}{c}2 \\
(2 ; 2 \\
2)\end{array}$ & $\begin{array}{c}2 \\
(2 ; 2 \\
2)\end{array}$ & $\begin{array}{c}1.3 \\
(1.3 ; 2 \\
1.3)\end{array}$ & 5.3 & 7.3 & \\
\hline 7 & $\begin{array}{c}\text { gully } \\
\text { Kamyshevatay, } \\
\text { hamlet } \\
\text { Kamyshovka }\end{array}$ & Orlovskij & 2 & $\begin{array}{l}1.3 \\
(1.3 ; \\
1.3 ; \\
1.3) \\
\end{array}$ & $\begin{array}{c}2 \\
(2 ; 2 \\
2)\end{array}$ & $\begin{array}{c}1.3 \\
(1.3 ; \\
1.3 ; 1.3)\end{array}$ & 4.6 & 6.6 & $\begin{array}{c}\text { recommended } \\
\text { with restrictions }\end{array}$ \\
\hline 8 & $\begin{array}{c}\text { Gully Dvojnaya, } \\
\text { reservoir } \\
\text { Razumejkinskoye2 } \\
.5 \mathrm{~km} \text { south of } \\
\text { Hamplet Luganskij }\end{array}$ & Orlovskij & 1 & $\begin{array}{l}0.7 \\
(0.7 \\
0.7 \\
0.7)\end{array}$ & $\begin{array}{l}1.3 \\
(2 ; \\
1.3 \\
2)\end{array}$ & $\begin{array}{c}1.3 \\
(1.3 ; \\
1.3 ; 1.3)\end{array}$ & 3.3 & 4.3 & $\begin{array}{l}\text { recommended } \\
\text { with significant } \\
\text { restrictions }\end{array}$ \\
\hline 9 & $\begin{array}{c}\text { gully Mokraya } \\
\text { Elmuta, } \\
12 \mathrm{~km} \text { north-west } \\
\text { of Proletarsk }\end{array}$ & $\begin{array}{l}\text { Proletars } \\
\text { kij }\end{array}$ & 0 & $\begin{array}{c}2 \\
(2 ; 2 \\
2)\end{array}$ & $\begin{array}{l}1.3 \\
(2 ; 2 \\
1.3)\end{array}$ & $\begin{array}{c}0.7 \\
(1.3 ; 2 \\
0.7)\end{array}$ & 4.0 & 4.0 & $\begin{array}{c}\text { not } \\
\text { recommended }\end{array}$ \\
\hline $\begin{array}{l}1 \\
0\end{array}$ & $\begin{array}{c}\text { the Rassypnaya } \\
\text { river, } \\
\text { v. Rassypnoye }\end{array}$ & $\begin{array}{l}\text { Peschano } \\
\text { kopskij }\end{array}$ & 2 & $\begin{array}{l}1.3 \\
(1.3 ; \\
1.3 \\
1.3) \\
\end{array}$ & $\begin{array}{c}2 \\
(2 ; 2 \\
2)\end{array}$ & $\begin{array}{c}2 \\
(2 ; 2 ; 2)\end{array}$ & 5.3 & 7.3 & recommended \\
\hline $\begin{array}{l}1 \\
1\end{array}$ & $\begin{array}{c}\text { gully pond } \\
\text { v.Zhukovskoye }\end{array}$ & $\begin{array}{c}\text { Peschano } \\
\text { kopskij }\end{array}$ & 1 & $\begin{array}{l}1.3 \\
(1.3 ; \\
1.3 ; \\
1.3) \\
\end{array}$ & $\begin{array}{c}2 \\
(2 ; 2 \\
2)\end{array}$ & $\begin{array}{c}1.3 \\
(1.3 ; 2 \\
1.3)\end{array}$ & 4.6 & 5.6 & $\begin{array}{c}\text { recommended } \\
\text { with restrictions }\end{array}$ \\
\hline $\begin{array}{l}1 \\
2\end{array}$ & $\begin{array}{l}\text { Reservoir on the } \\
\text { river Yula, }\end{array}$ & Salskij & 1 & $\begin{array}{c}0 \\
(0.7 \\
0.7 ; 0)\end{array}$ & $\begin{array}{c}1.3 \\
(1.3 \\
1.3 \\
1.3) \\
\end{array}$ & $\begin{array}{c}1.3 \\
(2 ; 1.3 \\
1.3)\end{array}$ & 3.3 & 4.3 & $\begin{array}{c}\text { not } \\
\text { recommended }\end{array}$ \\
\hline $\begin{array}{l}1 \\
3\end{array}$ & $\begin{array}{l}\text { pond, vill. } \\
\text { Voronovo }\end{array}$ & Tselinskij & 2 & $\begin{array}{l}1.3 \\
(1.3 ; \\
1.3 ; \\
1.3) \\
\end{array}$ & $\begin{array}{l}1.3 \\
(2 ; \\
1.3 \\
2) \\
\end{array}$ & $\begin{array}{c}1.3 \\
(1.3 ; 2 \\
1.3)\end{array}$ & 3.9 & 5.9 & $\begin{array}{c}\text { recommended } \\
\text { with restrictions }\end{array}$ \\
\hline $\begin{array}{l}1 \\
4\end{array}$ & $\begin{array}{c}\text { pond of the river } \\
\text { Middle Egorlyk, } \\
\text { vill. Sladkaya } \\
\text { Balka } \\
\end{array}$ & Tselinskij & 2 & $\begin{array}{l}1.3 \\
(1.3 ; \\
1.3 \\
1.3) \\
\end{array}$ & $\begin{array}{l}1.3 \\
(2 ; \\
1.3 \\
1.3) \\
\end{array}$ & $\begin{array}{c}1.3 \\
(1.3 ; \\
1.3 ; 1.3)\end{array}$ & 3.9 & 5.9 & $\begin{array}{c}\text { recommended } \\
\text { with restrictions }\end{array}$ \\
\hline 1 & pond & Egorlyks & 1 & 2 & 1.3 & 2 & 5.3 & 6.3 & recommended \\
\hline
\end{tabular}




\begin{tabular}{|c|c|c|c|c|c|c|c|c|c|}
\hline № & $\begin{array}{c}\text { Reservoir and its } \\
\text { location }\end{array}$ & $\begin{array}{l}\text { Region } \\
\text { studied }\end{array}$ & $\begin{array}{l}\text { First set } \\
\text { of issues }\end{array}$ & $\begin{array}{c}\text { Second } \\
\text { set of } \\
\text { issues }\end{array}$ & $\begin{array}{l}\text { Third } \\
\text { set of } \\
\text { issues }\end{array}$ & $\begin{array}{l}\text { Fourth } \\
\text { set of } \\
\text { issues }\end{array}$ & $\begin{array}{c}\text { Hydroch } \\
\text { emistry, } \\
\text { total }\end{array}$ & $\begin{array}{c}\text { Summa } \\
\text { rized } \\
\text { score }\end{array}$ & $\begin{array}{l}\text { Recommendation } \\
\mathrm{s} \text { for fish farming }\end{array}$ \\
\hline 5 & $\begin{array}{c}\text { «Vorobjaychka», } \\
\text { vill. Egorlykskaya }\end{array}$ & kij & & $\begin{array}{c}(2 ; 2 ; \\
2)\end{array}$ & $\begin{array}{c}2 \\
1.3 \\
2)\end{array}$ & $(2 ; 2 ; 2)$ & & & with restrictions \\
\hline $\begin{array}{l}1 \\
6\end{array}$ & $\begin{array}{c}\text { channel pond river } \\
\text { Kavalerka, hamlet } \\
\text { Kavalerskij }\end{array}$ & $\begin{array}{c}\text { Egorlyks } \\
\text { kij } \\
\text { Egorlyks } \\
\text { kij }\end{array}$ & 1 & $\begin{array}{c}2 \\
(2 ; 2 \\
2)\end{array}$ & $\begin{array}{l}2 \\
(2 ; 2 ; \\
2)\end{array}$ & $\begin{array}{c}1.3 \\
(2 ; 1.3 \\
2)\end{array}$ & 5.3 & 6.3 & $\begin{array}{l}\text { recommended } \\
\text { with restrictions }\end{array}$ \\
\hline $\begin{array}{l}1 \\
7\end{array}$ & $\begin{array}{c}\text { channel pond on } \\
\text { the Srednij Elbuzd } \\
\text { river } \\
\text { vil. Krajnij } \\
\end{array}$ & $\begin{array}{l}\text { Zernogra } \\
\text { dskij }\end{array}$ & 1 & $\begin{array}{l}1.3 \\
(1.3 ; \\
1.3 \\
1.3) \\
\end{array}$ & $\begin{array}{l}2 \\
(2 ; 2 ; \\
2)\end{array}$ & $\begin{array}{c}2 \\
(2 ; 2 ; 2)\end{array}$ & 5.3 & 6.3 & $\begin{array}{l}\text { recommended } \\
\text { with restrictions }\end{array}$ \\
\hline $\begin{array}{l}1 \\
8\end{array}$ & $\begin{array}{c}\text { pond on the Malyj } \\
\text { Elbuzd river, } 7 \mathrm{~km} \\
\text { west of hamlet } \\
\text { Revolyutsionnyj }\end{array}$ & $\begin{array}{l}\text { Zernogra } \\
\text { dskij }\end{array}$ & 1 & $\begin{array}{c}1.3 \\
(2 ; 1.3 \\
1.3)\end{array}$ & $\begin{array}{l}2 \\
(2 ; 2 ; \\
2)\end{array}$ & $\begin{array}{c}1.3 \\
(1.3 \\
1.3 ; 1.3)\end{array}$ & 4.6 & 5.6 & $\begin{array}{l}\text { recommended } \\
\text { with restrictions }\end{array}$ \\
\hline $\begin{array}{l}1 \\
9\end{array}$ & $\begin{array}{c}\text { pond Tkachev } \\
\text { (Polyachanskij), } \\
\text { hamlet } \\
\text { Kamyshevakha } \\
\end{array}$ & $\begin{array}{l}\text { Kagalnits } \\
\text { kij }\end{array}$ & 1 & $\begin{array}{c}2 \\
(2 ; 2 \\
2)\end{array}$ & $\begin{array}{l}2 \\
(2 ; 2 ; \\
2)\end{array}$ & $\begin{array}{c}2 \\
(2 ; 2 ; 2)\end{array}$ & 6.0 & 7.0 & recommended \\
\hline $\begin{array}{l}2 \\
0\end{array}$ & $\begin{array}{l}\text { pond of the village } \\
\text { Srednij Manych }\end{array}$ & $\begin{array}{c}\text { Veselovs } \\
\text { kij }\end{array}$ & 1 & $\begin{array}{c}2 \\
(2 ; 2 ; \\
2) \\
\end{array}$ & $\begin{array}{c}2 \\
(2 ; 2 ; \\
2) \\
\end{array}$ & $\begin{array}{c}1.3 \\
(2 ; 2 ; \\
1.3) \\
\end{array}$ & 5.3 & 6.3 & $\begin{array}{l}\text { recommended } \\
\text { with restrictions }\end{array}$ \\
\hline $\begin{array}{l}2 \\
1\end{array}$ & $\begin{array}{c}\text { lake } \\
\text { Kirsanovskoye, } \\
\text { floodplain of the } \\
\text { river Sal, } \\
\text { hamlet Kirsanovka } \\
\end{array}$ & $\begin{array}{l}\text { Martynov } \\
\text { skij }\end{array}$ & 1 & $\begin{array}{c}2 \\
(2 ; 2 \\
2)\end{array}$ & $\begin{array}{l}1.3 \\
(2 ; \\
1.3 \\
2)\end{array}$ & $\begin{array}{c}2 \\
(2 ; 2 ; 2)\end{array}$ & 5.3 & 6.3 & $\begin{array}{l}\text { recommended } \\
\text { with restrictions }\end{array}$ \\
\hline $\begin{array}{l}2 \\
2\end{array}$ & lake Voinskoye & $\begin{array}{c}\text { Konstanti } \\
\text { novskij }\end{array}$ & 1 & $\begin{array}{c}2 \\
(2 ; 2 ; \\
2)\end{array}$ & $\begin{array}{c}0 \\
(0.7 ; \\
0 ; 0)\end{array}$ & \begin{tabular}{|c|}
0.7 \\
$(1.3 ; 1.3 ;$ \\
$0.7)$
\end{tabular} & 2.7 & 3.7 & $\begin{array}{c}\text { not } \\
\text { recommended }\end{array}$ \\
\hline $\begin{array}{l}2 \\
3\end{array}$ & lake Ilmen & $\begin{array}{c}\text { Semikara } \\
\text { korskij }\end{array}$ & 1 & $\begin{array}{c}2 \\
(2 ; 2 ; \\
2)\end{array}$ & $\begin{array}{c}0 \\
(0.7 ; \\
0 ; 0)\end{array}$ & \begin{tabular}{|c|}
0.7 \\
$(1.3 ;$ \\
$0.7 ; 0.7)$ \\
\end{tabular} & 2.7 & 3.7 & $\begin{array}{c}\text { not } \\
\text { recommended }\end{array}$ \\
\hline $\begin{array}{l}2 \\
4\end{array}$ & $\begin{array}{l}\text { lake Peschanyj } \\
\text { Liman }\end{array}$ & $\begin{array}{l}\text { Bagaevsk } \\
\text { ij }\end{array}$ & 2 & $\begin{array}{c}2 \\
(2 ; 2 \\
2)\end{array}$ & $\begin{array}{c}1.3 \\
(1.3 \\
1.3 \\
2)\end{array}$ & $\begin{array}{c}2 \\
(2 ; 2 ; 2)\end{array}$ & 5.3 & 7.3 & recommended \\
\hline
\end{tabular}

Note: in brackets the point coefficient is indicated in different seasons of the year - spring, summer and autumn [16-17].

Thus, in the southern and southeastern territories of the Rostov region, among the water bodies studied, according to hydrological and hydrochemical parameters $21 \%$ of water bodies are recommended for fish farming, 54\% are recommended with restrictions, $4 \%$ are recommended with significant restrictions, and $21 \%$ are not recommended at all.

The territorial location of the water bodies studied and their ranking according to suitability for aquaculture purposes are shown in Figure 2. 


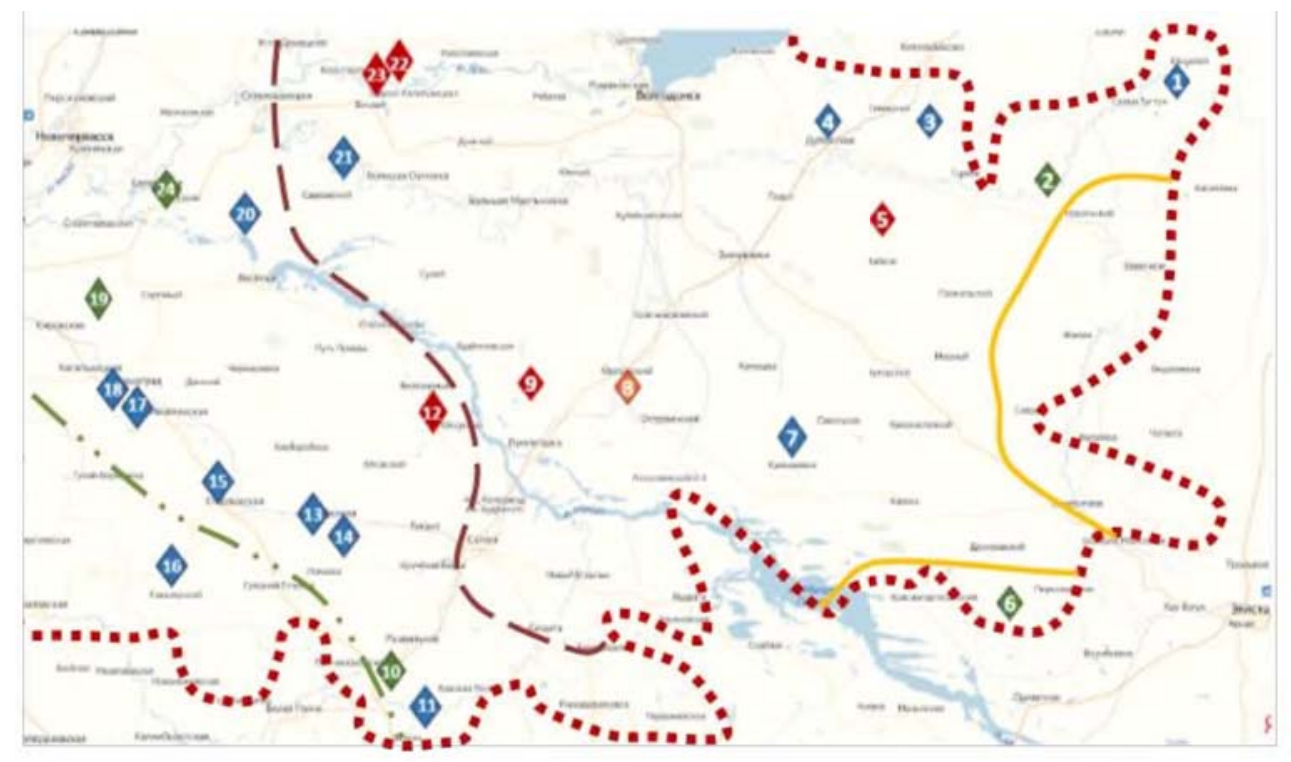

Fig. 2. Mapping of the studied water bodies and their ranking according to suitability for commercial fish farming

Legend:

recommended
recommended with limitations
pond number corresponds to table 1
(precipitation ratio $<0.33)$;
- wery arid (precipitation ratio $=0.33$ - 0.44 ) and arid zones (precipitation ratio $=0.45-0.55$ );
According to the above-mentioned scoring characteristics, the dependence analysis of the
suitability of the reservoir for fish breeding on the territorial location, the average annual flow rate of
the rivers or the annual precipitation ratio showed the absence of reliable correlations. At the same
time, it should be noted that at a low precipitation ratio corresponding to a semi-dry climate and
constituting $<0.33$ (in Figure 3 it is indicated under number 1 along the $X$-axis), we studied
only one waterbody, namely, Tikholimanskoye reservoir of the Remontnensky district,
where no restrictions were established on fish farming (Figure 3 ). A distinctive feature of
the water body investigated was a high drainage area (in km2) - the ratio of the catchment
area to the area of the reservoir was more than 2600 , which ensured a sufficient flow of
water and the resistance of this reservoir to drying out.




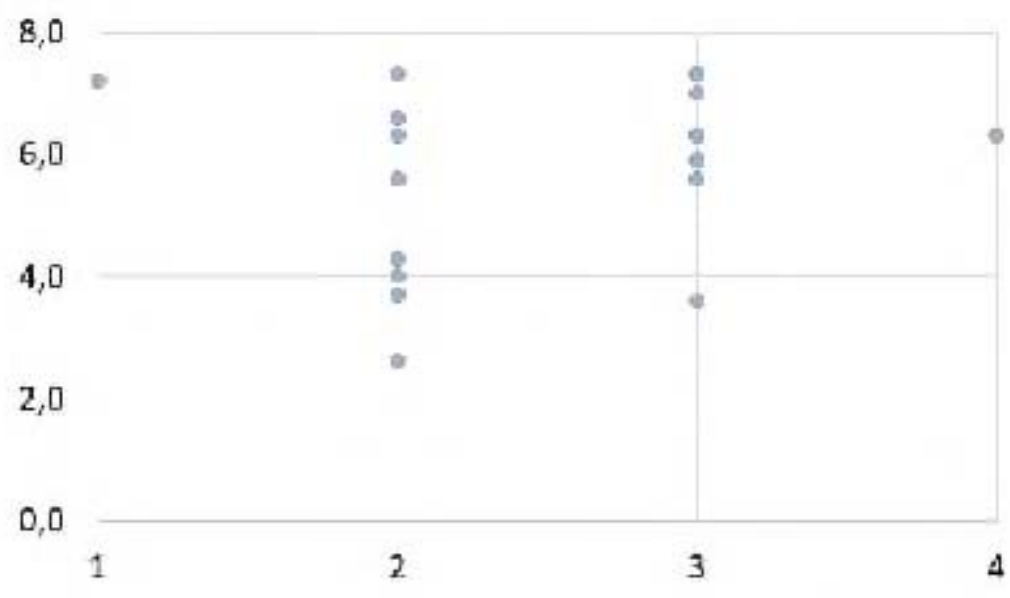

Fig. 3. The relationship of the point characteristics of ponds and the average annual precipitation ratio

In a very arid climate with a precipitation ratio being 0.33-0.44 (designated in Figure 3 along the $\mathrm{X}$-axis as number 2), the variability of the scatter of scoring characteristics by hydrological and hydrochemical criteria was the highest, namely from 2.6 to 7.3 points. Of the 11 investigated reservoirs in this zone, four water bodies were not recommended for commercial cultivation of aquatic biological resources, and one was recommended with significant restrictions. With a precipitation ratio of 0.45-0.55 (designated in Figure 3 on the $\mathrm{X}$-axis at number 3 ) in an arid climate, almost all the water bodies under study were recommended or recommended with restrictions for commercial fish farming. Only one reservoir situated on the river Yula was not recommended for fish farming. In a mildly arid climate with a precipitation ratio of $0.55-0.70$ (designated in Figure 3 along the $\mathrm{X}$-axis at number 4), one reservoir (the Polyachansky pond of the Kagalnitsky district) was investigated, which was also recommended for fish farming.[18]

It should be noted that after studying the materials collected throughout the Rostov region and where further research is being carried out, it is quite possible to identify areas and zones with different degrees of potential for applying waterbodies for aquaculture purposes.

Thus, in spite of the fact that practically all the water bodies according to the conditions of moisture supply should be attributed to reservoirs with risky fish farming, the number of not recommended or recommended with significant restrictions water bodies accounted for only $25 \%$ of the total. This indicates a high potential for fish farming even in the arid zone of the Rostov region.[19]

\section{Conclusion}

1. A point score is proposed for several sets of issues and some criteria are defined for a comprehensive assessment of commercial aquaculture facilities in the southern and southeastern

Rostov region on the basis of hydrological and hydrochemical characteristics.

2. The total score established according to the proposed scheme of assessment of waterbodies by hydrological and hydrochemical characteristics can be used as the criteria for their suitability for commercial aquaculture purposes. 
3. All water bodies according to the conditions of moisture supply should be classified as reservoirs with risky fish farming. According to the above scoring characteristics, we have not revealed the dependence of the suitability of the reservoir for fish farming on the territorial location, on the average annual flow rate of the rivers or the annual precipitation ratio, only in the zone of a very arid climate more unusable water bodies were found. This indicates a high potential for fish farming even in the arid zone of the Rostov region.

4. Brief hydrological and hydrochemical characteristics of each investigated water body can be used to propose scientifically based recommendations for the organization of fish farms for commercial aquaculture.

5. Further research according to the specified criteria of waterbodies on the rest territory of the Rostov region may allow zoning of the entire territory of the region with an indication of the reservoirs suitable for commercial aquaculture purposes.

\section{References}

1. A. R. Skrzypczak, A. Napiórkowska-Krzebietke, Aquaculture Reports, 18, 126 - 128 (2020) doi.org/10.1016/j.aqrep.2020.100460

2. Z. Han, Sh. Wang, Journal of Environmental Management, 268, 325-328 (2020) doi.org/10.1016/j.jenvman.2020.110661

3. Z. Adámek, M. Mössmer, doi.org/10.1016/j.aquaculture.2019.734261

Aquaculture, $\quad \mathbf{5 1 2}$

4. M. Bennion, L. Morrison, Science of The Total Environment, 685, 50-58 (2019), doi.org/10.1016/j.scitotenv.2019.05.233

5. Cheng-ShinJang, Shih-Kai Chen, Journal of Hydrology, 414-415, 201-210 (2012) doi.org/10.1016/j.jhydrol.2011.10.032

6. N. C. Ferreira, C. Bonetti, Aquaculture, 318, 425-433 (2011) doi.org/10.1016/j.aquaculture.2011.05.045

7. J. Sun, Ch. Tang, Journal of Hydrology, 504, 115-124 (2013) doi.org/10.1016/j.jhydrol.2013.09.029

8. M. Raczyńska, S. Machula, Acta Ecologica Sinica, 32, 160-164, (2012) doi.org/10.1016/j.chnaes.2012.04.003

9. Cheng-Shin Jang, Yi-Ting Liou, 388, 491-500 doi.org/10.1016/j.jhydrol.2010.05.033

10. K. Stefanidis, Y. Panagopoulos, Science of The Total Environment, 627, 756-769 (2018) doi.org/10.1016/j.scitotenv.2018.01.282

11. Nur Aliaa Shafie, A. Zaharin Aris, International Journal of Sediment Research, 29, 368-377 (2014) doi.org/10.1016/S1001-6279(14)60051-2

12. J. G. Tundisi, Water Security, 4-5, 1-7 2018 doi.org/10.1016/j.wasec.2018.09.001

13. Si-Liang Li, Sen Xu, Agriculture, Ecosystems \& Environment, 303, 107-120 (2020) doi.org/10.1016/j.agee.2020.107120

14. H. Trannum, H. Gundersen, Journal of Sea Research, 141, 83-98 (2018) doi.org/10.1016/j.seares.2018.08.007

15. J. López-Luna, M. Ibáñez, Aquacultural Engineering, 54, 22-28 (2013) doi.org/10.1016/j.aquaeng.2012.10.005

16. M. Mazanko, E. Prazdnova, D. Rudoy, A. Ermakov, A. Olshevskaya, T. Maltseva, E3S Web of Conferences, 175, 01010 (2020) INTERAGROMASH 2020 https://doi.org/10.1051/e3sconf/202017501010 
17. A. Altybayev, Y. Naydenko, B. Meskhi, A. Mozgovoy, D. Rudoy, A. Olshevskaya, E3S Web of Conferences, INTERAGROMASH, 175, 03019 (2020) https://doi.org/10.1051/e3sconf/202017503019

18. E. Sokolova, V. Orobets, O. Sevostyanova, E. Gorchakov, D. Rudoy, A. Olshevskaya, A. Babajanyan, E3S Web of Conferences, INTERAGROMASH, 175, 03015 (2020) https://doi.org/10.1051/e3sconf/202017503015

19. A. A. Korotky, S. I. Popov, G. A. Galchenko, Ju. V. Marchenko, D. S. Drozdov, The use of SmartBox container for agrobusiness logistic processes optimization, XIII International Scientific and Practical Conference «State and Prospects for the Development of Agribusiness - INTERAGROMASH 2020»: E3S Web of Conferences, 175, 13019 (2020) doi.org/10.1051/e3sconf/202017513019 